\title{
Studying the influence of the carbon dioxide injection period duration on the gas recovery factor during the gas condensate fields development under water drive
}

\author{
Serhii Matkivskyi ${ }^{* \otimes} \otimes\left(\mathbb{0}\right.$, Oleksandr Kondrat ${ }^{2 \otimes}$ (1) \\ ${ }^{1}$ JSC Ukrgasvydobuvannya, Ukrainian Scientific-Research Institute of Natural Gases, Kharkiv, 61010, Ukraine \\ ${ }^{2}$ Ivano-Frankivsk National Technical University of Oil and Gas, Ivano-Frankivsk, 76019, Ukraine \\ *Corresponding author: e-mail matkivskyi.sergey@ndigas.com.ua, tel. +380961746604
}

\begin{abstract}
Purpose. Studying the process of carbon dioxide injection at the boundary of the initial gas-water contact in order to slow down the formation water inflow into producing reservoirs and increase the final hydrocarbon recovery factors.

Methods. To assess the influence on gas recovery factor of the duration of carbon dioxide injection period at the initial gaswater contact, a reservoir development is studied using the main Eclipse and Petrel hydrodynamic modeling tools of the Schlumberger company on the example of a hypothetical three-dimensional model of a gas-condensate reservoir.

Findings. The dependence of the main technological indicators of reservoir development on the duration of the carbon dioxide injection period at the initial gas-water contact has been determined. It has been revealed that an increase in the duration of the non-hydrocarbon gas injection period leads to a decrease in the formation water cumulative production. It has been found that when injecting carbon dioxide, an artificial barrier is created due to which the formation water inflow into the gas-saturated intervals of the productive horizon is partially blocked. The final gas recovery factor when injecting carbon dioxide is $61.98 \%$, and when developing the reservoir for depletion $-48.04 \%$. The results of the research performed indicate the technological efficiency of carbon dioxide injection at the boundary of the initial gas-water contact in order to slow down the formation water inflow into producing reservoirs and increase the final hydrocarbon recovery factors for the conditions of a particular field.
\end{abstract}

Originality. The optimal value of duration of the carbon dioxide injection period at the initial gas-water contact has been determined, which is 16.32 months based on the statistical processing of calculated data for the conditions of a particular field.

Practical implications. The use of the results makes it possible to improve the existing technologies for the gas condensate fields development under water drive and to increase the final hydrocarbon recovery factor.

Keywords: 3D model, hydrocarbon field, gas condensate reservoir, water drive, carbon dioxide injection

\section{Introduction}

The results of hydrogeology survey, as well as data on formation water obtained from prospecting and exploratory drilling of wells, from which during testing the reservoir water inflows were obtained, make it possible to characterize the peculiarities of the hydrogeological system within the field.

Determining the gas-water contact position is an important task of control, without which rational reservoirs development is impossible. The choice of optimal control complex over the gas-water contact should be based on modern scientifictechnical achievements and industrial experience [1].

The factors of hydrocarbons recovery from producing reservoirs, which are characterized by an active water drive of development, are $70-85 \%$ [2]. The more active the water- pressure system, the greater the saturation with the residual gas and the lower the hydrocarbon recovery factor.

The main methods of controlling the field development process include plotting the dependence of the reduced reservoir pressure on the gas cumulative production from the field [3]. Using the graphical-analytical dependence, the mode of field development and the initial/residual drained gas reserves are determined. It also makes possible to assess the water-pressure system activity, when the formation water inflows into producing reservoirs, and the nature of drainage in the producing reservoirs [4].

There are methods that are used to prevent the formation water inflow and to resist water-cut in producing wells. They are aimed at minimizing the negative impact of the water 
drive on the development process and increase in the final hydrocarbon recovery factor.

As a results of multi-year research, three main methods for increasing the gas production from water-cut gascondensate fields have been proposed.

One of these methods is the production of residual trapped gas by continuing the water-cut wells operation with the next extraction of gas from the gas-liquid mixture [5]-[8]. This method has significant disadvantages. The main disadvantage is related to the utilization of large volumes of produced formation water in comparison with the produced trapped gas volumes.

The second method is the joint gas and water extraction. According to this method, gas is extracted from wells, which, in terms of hypsometry, are higher and are operated from the gas part of the reservoir. Water is produced from wells located at the boundary of the gas-water contact [9], [10]. This method is effective for gas fields with an inactive and active water-pressure system.

According to the third method, gas is extracted at a significantly higher rate compared to the rate of water inflow. The purpose of this technology is that in a short period of time, it is necessary to recover as much gas as possible before the formation water breakthrough and water-cut of producing reservoirs and producing wells [11]-[14].

Based on the research [15], it has been revealed that an increase in the rate of gas extraction does not always lead to an increase in the hydrocarbon recovery factor and depends on the reservoir porosity and permeability, as well as on the zonal heterogeneity of producing reservoirs.

Currently, a significant number of theoretical and experimental studies have been performed related to the hydrocarbon fields development under water drive regime. Based on the results of domestic and foreign studies, the mechanism of behaviour of the gas trapped by water in a porous medium has been revealed. On the basis of fundamental research results, a large number of methods and technologies have been developed, however, the vast majority of them are characterized by significant disadvantages and are ineffective. Therefore, there is a need for improvement of existing and development of new technologies that provide maximum hydrocarbon recovery factors at the lowest cost.

Today, the tendency of increasing the hydrocarbon production from gas and gas condensate fields by injecting nonhydrocarbon gases (nitrogen, carbon dioxide, flue and eshaust gases, mixtures of various gases) remains promising [16]-[20].

One of the successful technologies in the field of secondary gas extraction is the technology of injecting the carbon dioxide into the producing reservoir. Theoretical and experimental research on the process of carbon dioxide injection with the aim of displacing the residual gas and increasing the hydrocarbon recovery factor confirm its effectiveness [21]-[23].

Based on the previous research results, it has been determined that due to the carbon dioxide injection, it is possible to additionally recover a significantly larger volume of gas compared to the options of the field development for depletion and to provide significantly higher final gas recovery factors [24]-[26].

Numerous studies have confirmed that carbon dioxide dissolves well in water with increasing pressure, but sharply decreases with increasing temperature and salinity of water. Given the above, it can be argued that carbon dioxide will expand and partially dissolve in water, while slowing down the formation water inflow into producing reservoirs [27].

According to the experimental research [28], it has been determined that in most cases, to ensure a more complete coverage of the gas-saturated zone of the reservoir, it would be desirable to completely prevent the formation water inflow into producing reservoir. However, a practical solution to this problem has not yet been found.

Theoretical and experimental research on the process of injecting non-hydrocarbon gases with the aim to displace residual gas and increasing the hydrocarbon recovery factor confirm its effectiveness. However, the problem of choosing the injection agent that will provide the greatest effect has not yet been studied.

The research purpose is to study the influence on the natural gas recovery factor of the period duration of carbon dioxide injection into a producing reservoir using numerical modeling.

To achieve this purpose, the following objectives are set:

1. Study the influence of varying durations of the carbon dioxide injection period at the boundary of the initial gaswater contact on the main technological indicators of the producing reservoir development.

2. Determine the optimal duration of the carbon dioxide injection period at the boundary of the initial gas-water contact for the conditions of a particular reservoir.

3. Substantiate the efficiency of the technology for injecting the carbon dioxide into a producing reservoir for its injection period optimal duration.

\section{Research methods}

Research is performed using the main Eclipse and Petrel hydrodynamic modeling tools of the Schlumberger company (USA) on the example of a hypothetical homogeneous threedimensional model of a gas condensate reservoir.

A producing reservoir is represented by a circular-shaped model. The gas-bearing area of the formation is $17.63 \cdot 10^{6} \mathrm{~m}^{2}$, reservoir thickness $-15.4 \mathrm{~m}$, coefficient of porosity -0.18 , initial gas saturation coefficient -0.8 , reservoir absolute permeability coefficient $-8.65 \cdot 10-^{3} \mathrm{mcm}$, average depth of producing reservoir- $3300 \mathrm{~m}$, initial reservoir pressure $-35 \mathrm{MPa}$, reservoir temperature $-358 \mathrm{~K}$. Gas reserves amount to $800.97 \mathrm{mln}^{3}$.

A conceptual digital 3D model of a gas condensate reservoir is shown in Figure 1.

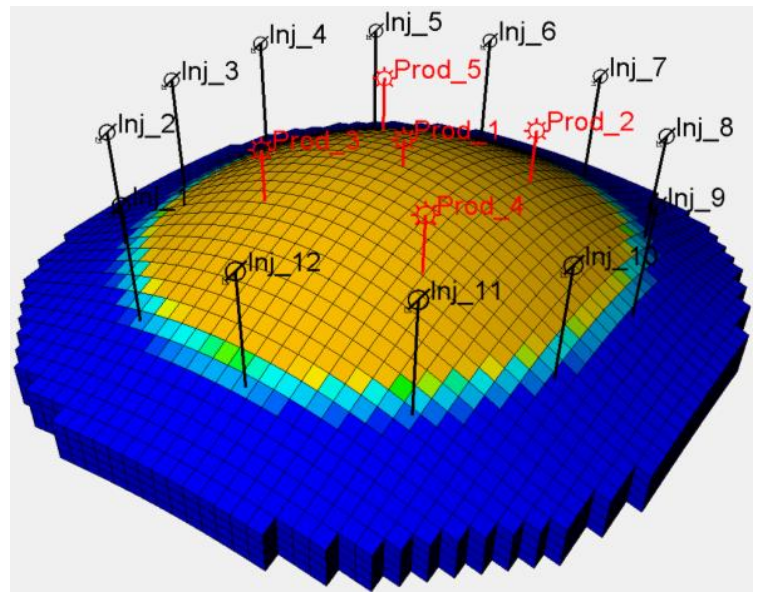

Figure 1. Conceptual digital 3D model of a gas condensate reservoir 
A producing reservoir is being developed for depletion using 5 producing wells. The gas flow rate of the producing well is 50 thous. $\mathrm{m}^{3} /$ day. Along the perimeter of initial gaswater contact, 12 injection wells are placed. Carbon dioxide is injected at a rate of 50 thous. $\mathrm{m}^{3} /$ day in a single well. The research is conducted for various values of the period duration of carbon dioxide injection into the producing reservoir (12, $14,16,18,21,24$ months). Upon reaching the predetermined duration of the carbon dioxide injection period, the injection is stopped, and further operation of the producing wells continues until the injection agent breaks into the producing wells.

In order to take into account the physical processes that occur during gas filtration in the reservoir during the carbon dioxide injection under water drive, a compositional model for a gas condensate reservoir has been created and used [29], [30].

In the course of research, for the option with the nonhydrocarbon gas injection into the producing reservoirs, the moment of carbon dioxide breakthrough into each of the producing wells is recorded. In this case, the producing wells are stopped at the moment of carbon dioxide breakthrough. To assess the value of the effect obtained from the studied technology introduction in the case of development for depletion, the producing wells are stopped at the same moment as it is during the development of reservoir with the carbon dioxide injection.

The different duration of period of the carbon dioxide injection into the producing reservoir specifies the different duration of the period of producing wells operation until the moment of its breakthrough. Given the above, for each option of a reservoir development with carbon dioxide injection, an option of development for depletion is calculated in accordance with the duration of the producing wells operation period.

Based on the research performed, the main technological indicators of a producing reservoir development at the moment of carbon dioxide breakthrough into one of the producing wells are calculated according to the amount of formation water produced at the moment of its breakthrough. The research results are processed in the form of dependency diagrams of the studied parameters at the moment of carbon dioxide breakthrough into producing wells on its injection period duration.

\section{Results and discussion}

When analyzing the calculation data, it has been determined that the carbon dioxide injection into the reservoir leads to a decrease in the volume of formation water production compared to the development of a producing reservoir for depletion. The dynamics of hydrocarbon cumulative production during the reservoir development for depletion and with a carbon dioxide injection period of 14 months is shown in Figure 2.

The results of modeling the process of producing reservoir development indicate that the carbon dioxide injection at the boundary of the initial gas-water contact ensures the maintenance of reservoir pressure at the high level in comparison with the reservoirs development for depletion.

The dynamics of reservoir pressure during the reservoir development for depletion and during the carbon dioxide injection for 14 and 24 months is shown in Figure 3.

When analyzing the calculation data, it is necessary to pay attention to the type of dependences of the reservoir pressure dynamics over time.

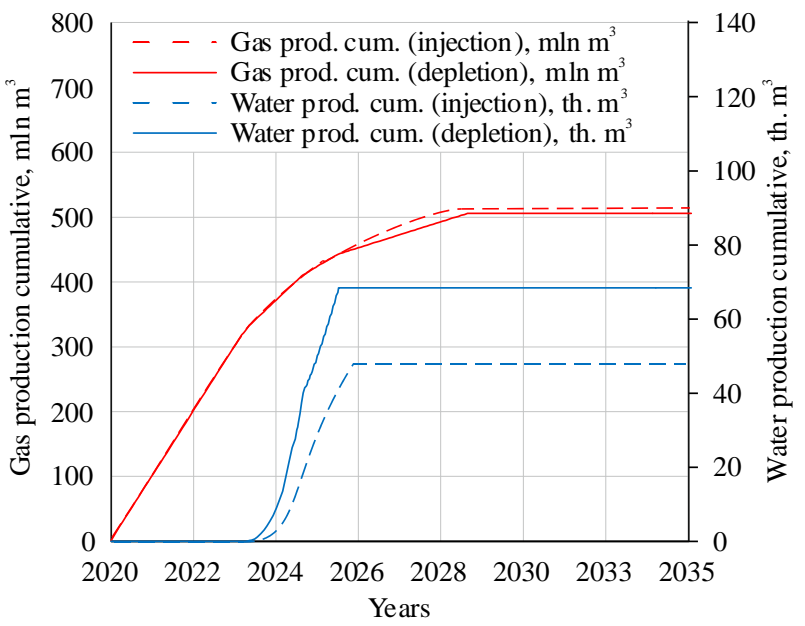

Figure 2. Dynamics of hydrocarbon cumulative production during the reservoir development for depletion and with a carbon dioxide injection period of 14 months

(a)

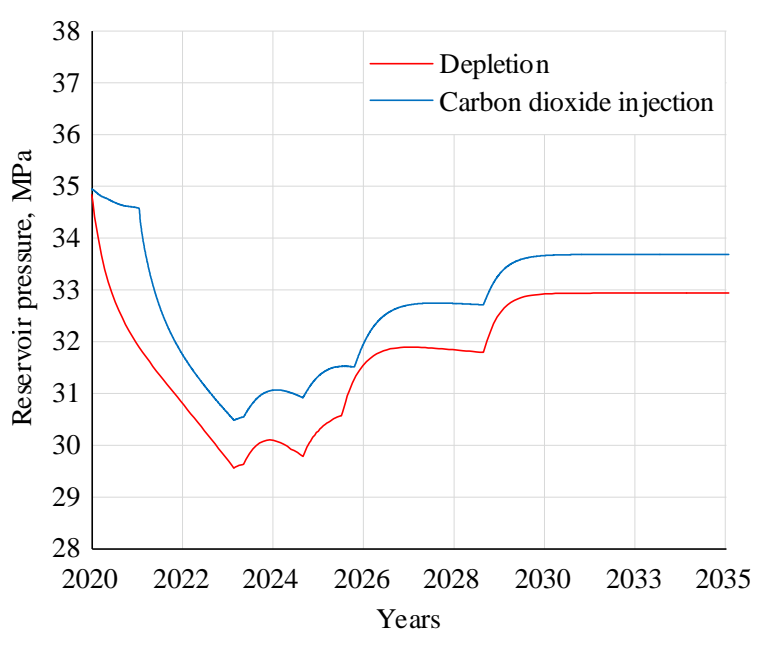

(b)

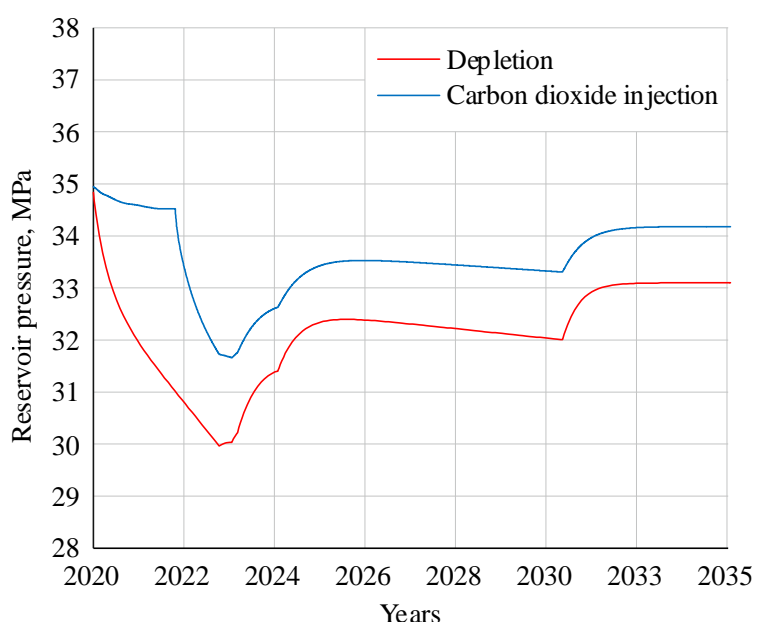

Figure 3. Dynamics of reservoir pressure during the reservoir development for depletion and during the carbon dioxide injection for 14 months (a) and 24 months (b)

Such nature of the change in reservoir pressure over time is conditioned by shutting-in of producing wells caused by the breakthrough of carbon dioxide, or flooding. Also, the activity of water-pressure system has a significant influence 
on the nature of the reservoir pressure change. Due to the formation water inflow into producing reservoirs, there is a partial compensation of natural gas offtake.

Based on the calculations, it has been determined that an increase in the duration of the dioxide injection period leads to a decrease in the duration of the reservoir additional development. For an injection period duration of 12 months, the carbon dioxide breakthrough into the first producing well occurs after 45 months of producing reservoir development, and for an injection period duration of 24 months, the breakthrough time is reduced to 37 months.

Thus, an increase in the injection period duration leads to a decrease in the hydrocarbon cumulative production due to the rapid carbon dioxide breakthrough into the producing wells. The longer the injection period duration, the faster carbon dioxide breaks through into the producing wells and the faster they shut down.

The dynamics of gas cumulative production depending on the duration of the carbon dioxide injection period is shown in Figure 4.

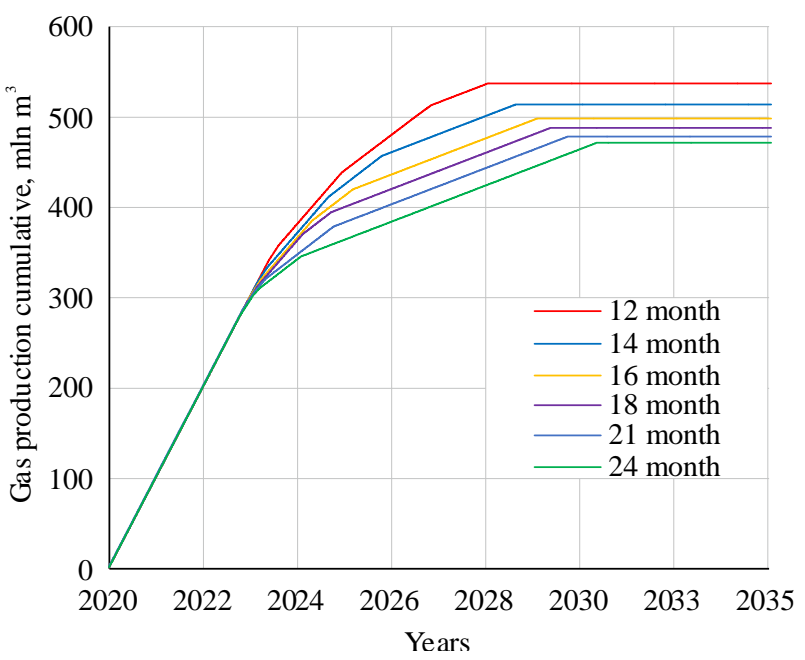

Figure 4. Dynamics of gas cumulative production depending on the duration of the carbon dioxide injection period

When analyzing the effectiveness of introducing the technology for carbon dioxide injection, it should be noted the cumulative production of formation water at the moment of carbon dioxide breakthrough into the producing wells and during the reservoir development for depletion.

With the carbon dioxide injection at the boundary of the initial gas-water contact for 12 months, the cumulative production of formation water at the moment of the carbon dioxide breakthrough into the producing wells is 19.838 thous. $\mathrm{m}^{3}$ of water. While during the development of a producing reservoir for depletion under these conditions, water production is 303.796 thous. $\mathrm{m}^{3}$. An increase in the duration of the non-hydrocarbon gas injection period up to 24 months leads to a decrease in the cumulative production of formation water to 0.037 thous. $\mathrm{m}^{3}$ in the option with injection and to 0.08 thous. $\mathrm{m}^{3}$ in the development of a producing reservoir for depletion.

Based on the research results, the dependence of the main technological indicators of producing reservoir development on the duration of the carbon dioxide injection period has been determined. The results of modeling the producing reservoir development process evidence that an increase in the duration of the carbon dioxide injection period leads to a decrease in the cumulative production of hydrocarbons and a sharp decrease in the production of formation water.

The dynamics of water cumulative production depending on the duration of the carbon dioxide injection period is shown in Figure 5.

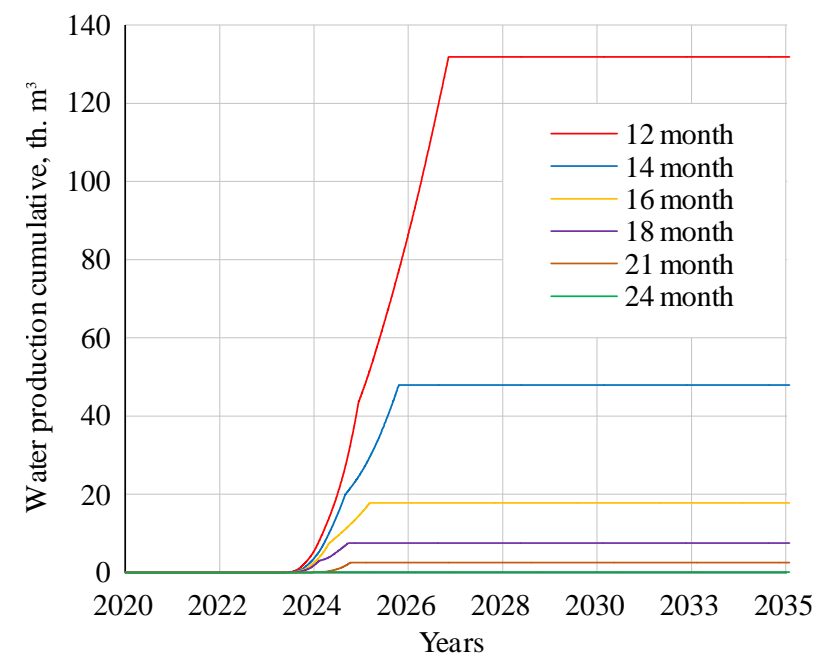

Figure 5. Dynamics of water cumulative production depending on the duration of the carbon dioxide injection period

The results obtained indicate the effectiveness of the technology for injecting carbon dioxide at the initial gaswater contact in order to slow down the formation water inflow into producing reservoirs.

The water cumulative production depending on the duration of the carbon dioxide injection period is: 12 months 131.89 thous. $\mathrm{m}^{3}$; 14 months -47.95 thous. $\mathrm{m}^{3}$; 16 months 17.81 thous. $\mathrm{m}^{3} ; 18$ months -7.44 thous. $\mathrm{m}^{3} ; 21$ months 2.55 thous. $\mathrm{m}^{3} ; 24$ months -0.032 thous. $\mathrm{m}^{3}$.

Given that the densities of carbon dioxide and water differ significantly, the process of its injection at the gas-water contact boundary partially prevents the formation water inflow into producing reservoirs by creating an artificial barrier between water and natural gas. This barrier partially blocks the selective inflow of formation water and thereby ensures stable waterless operation of producing wells.

When analyzing the state of producing reservoir watercut at the moment of carbon dioxide breakthrough into the producing wells with an injection period of 14 months and during development for depletion, it has been determined that in the case with carbon dioxide injection at the moment of its breakthrough into the producing wells, the current gas-water contact is significantly lower in the producing reservoir structure in comparison with the development for depletion.

The change in the gas-water contact position during the producing reservoir development is shown in Figure 6.

Based on the calculation data, the dependence of the gas recovery factor on the duration of the carbon dioxide injection period at the moment of its breakthrough into the producing wells has been determined. According to the analysis, an increase in the injection period duration from 12 to 24 months significantly influences on the gas recovery factor and amounts to: 12 months $-42.54 \%$; 14 months $-39.44 \%$; 16 months - 37.63\%; 18 months - 36.61\%; 21 months $35.64 \%$; 24 months $-34.96 \%$. 
(a)

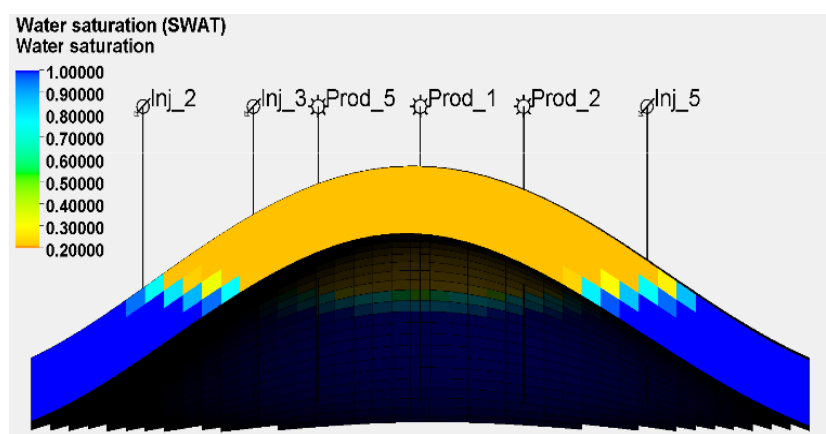

(b)

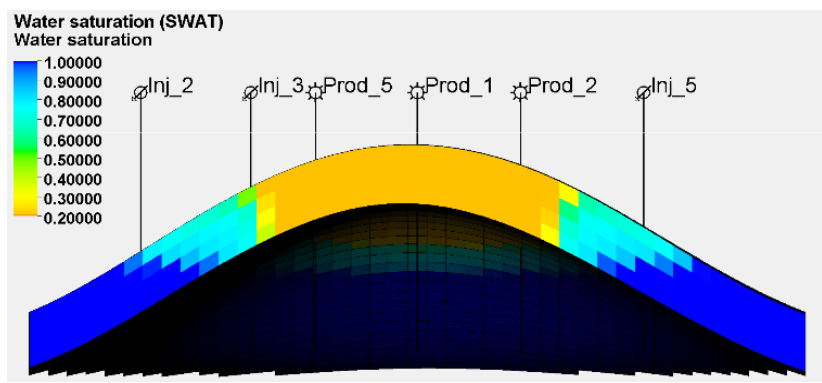

(c)

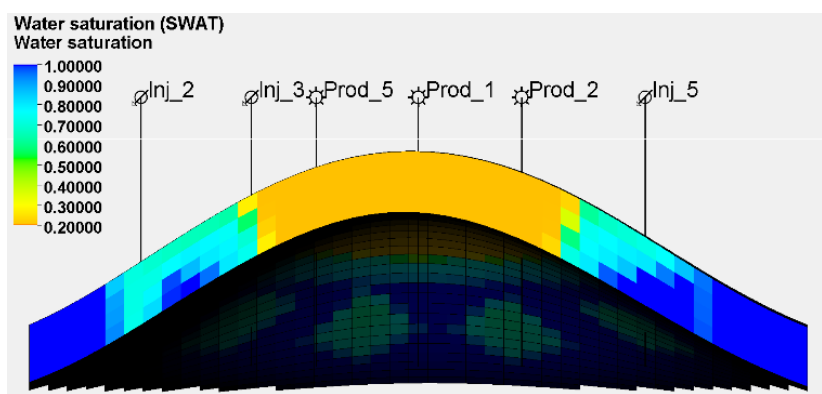

Figure 6. Position of the gas-water contact before the beginning of development (a), during development for depletion (b) and during the carbon dioxide injection (c) for 14 months at the moment of its breakthrough into the producing well

The dependences of the gas recovery factor on the duration of the carbon dioxide injection period at the moment of its breakthrough into producing wells and during the reservoir development for depletion are shown in Figure 7.

Based on the results of statistical processing the calculated data, the optimal value of duration of the carbon dioxide injection period into the reservoir, beyond which the gas recovery factor does not change significantly. At the moment of the carbon dioxide breakthrough into the producing well, the optimal value of the period duration of its injection into the reservoir is 16.32 months.

The final gas recovery factor for the given optimal value of injection period duration is $61.98 \%$. When developing a producing reservoir for depletion, the final gas recovery factor is $48.04 \%$

The research results evidence the technological efficiency of carbon dioxide injection into producing reservoirs at the boundary of the gas-water contact in order to slow down the formation water inflow into producing reservoirs and increase the final hydrocarbon recovery factor for the conditions of a particular field.

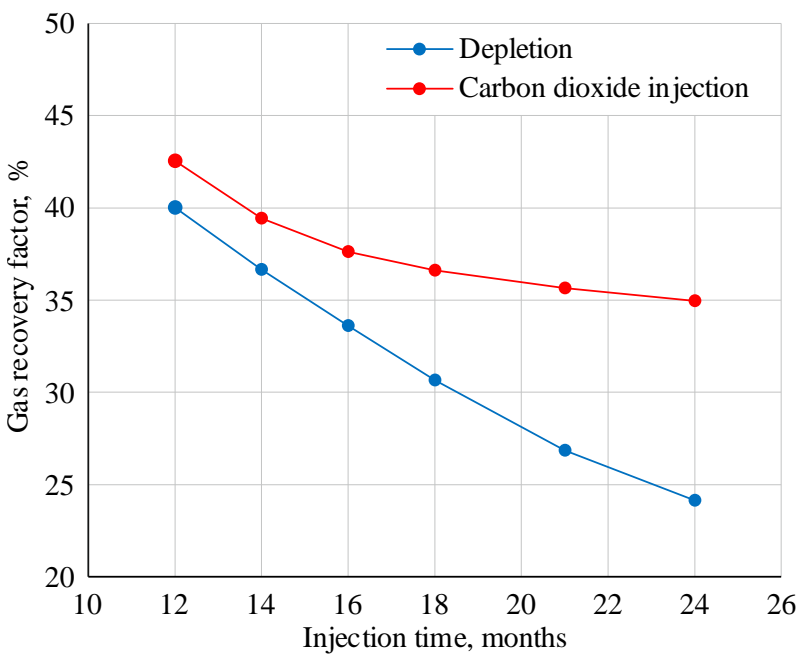

Figure 7. Dependences of the gas recovery factor on the duration of the carbon dioxide injection period at the moment of its breakthrough into producing wells and during the reservoir development for depletion

\section{Conclusions}

Modeling the hydrocarbon fields development, which are being developed under water drive pressure regime, makes it possible to gain certain experience in the implementation of complex methods for predicting hydrocarbon recovery from such fields. Through the use of numerical modeling, it is possible to determine what exactly needs to be done to stabilize the hydrocarbon recovery under various conditions.

Using Eclipse and Petrel, the main tools of hydrodynamic modeling based on a digital three-dimensional model, the influence of the duration of carbon dioxide injection period at the initial gas-water contact on the final gas recovery factor has been studied.

Based on the modeling results, the optimal value of the duration of carbon dioxide injection period at the initial gas-water contact has been calculated, which is 16.32 months. For the obtained optimal value of the duration of the carbon dioxide injection period, the final gas recovery factor can be $61.98 \%$. When developing a producing reservoir for depletion, the predicted gas recovery factor under such conditions is $48.04 \%$.

The final decision for implementing the carbon dioxide injection technology and optimal technological parameters for the producing and injection wells operation should be made on the basis of a comprehensive technical-andeconomic analysis.

\section{Acknowledgements}

The research results have been obtained without any support in the form of grants or projects. The authors express their gratitude to JSC Ukrgasvydobuvannya for the opportunity to conduct research, the results of which are presented in this paper.

\section{References}

[1] Boyko, V.S., Kondrat, R.M., \& Yaremiychuk, R.S. (1996). Dovidnyk z naftohazovoi spravy. Kyiv, Ukraina: Lviv, $620 \mathrm{~s}$.

[2] Firoozabadi, A., Olsen, G., \& Golf-Racht, V.T. (1987). Residual gas saturation in water-drive gas reservoir. SPE California Regional Meeting held in Ventura, California, 319-322. https://doi.org/10.2118/16355-ms 
[3] Matkivskyi, S.V., Kondrat, O.R., \& Khaydarova, L.I. (2020). Doslidzhennya vplyvu neznachnoho proyavu vodonapirnoyi systemy na dostovirnist' material'noho balansu kolektoriv. Rozvidka ta Rozrobka Naftovykh i Hazovykh Rodovyshch, 2(75), 43-51. https://doi.org/10.31471/1993-9973-2020-2(75)-43-51

[4] Zavaleta, S., Adrian, P.M., \& Michel, M. (2018). Estimation of OGIP in a water-drive gas reservoir coupling dynamic material balance and fetkovich aquifer model. SPE Trinidad and Tobago Section Energy Resources Conference. https://doi.org/10.2118/191224-ms

[5] Hower T.L., Bcrgeson I.E., Lewis D.R. and Owens R.W. (1992). Recovery optimization in a multi-reservoir offshore gas field with water influx. 67 $7^{\text {th }}$ Annual Technical Conference and Exhibition of the Society of Petroleum Engineers, 9-15. https://doi.org/10.2118/24865-ms

[6] Ancell, K.L., \& Trousil, P.M. (1990). Remobilization of natural gas trapped by encroaching water'. $65^{\text {th }}$ Annual Technical Conference and Exhibition of Society of Petroleum Engineers held in New Orleans, Louisiana, 375-381. https://doi.org/10.2118/20753-ms

[7] Matthew, J.D., Hawes, R.I., \& Lock, T.P. (1988). Feasibility studies of water flooding gas condensate reservoir. Journal of Petroleum Technology, 40(08), 1049-1056. https://doi.org/10.2118/15875-pa

[8] Calgle, T.O. (1990). Performance of secondary gas recovery operations: north Alazan H-21 reservoir. $65^{\text {th }}$ Annual Technical Conference and Exhibition of the Society of Petroleum Engineers held in New Orleans, Louisiana, 508-513. https://doi.org/10.2118/20771-ms

[9] Rogers, L.A. (1984). Test of secondary gas recovery by coproduction of gas and water from Mt. Selman Field, Texas'. Unconventional Gas Recovery Symposium, 331-335. https://doi.org/10.2118/12865-ms

[10] Arco, D.P., \& Bassiouni, Z. (1987). The technical and economic feasibility of enhanced gas recovery in the Eugene Island Field by use of coproduction technique, Louisiana State University. Journal of Petroleum Technology, 39(05), https://doi.org/10.2118/14361-pa

[11] Zakirov, S., Zakirov, I., \& Batanova, M. (2006). Novye printsipy tekhnologii razrabotki mestorozhdeniy nefti $i$ gaza. Moskva-Izhevsk, Rossiya: Institut komp'yuternykh tekhnologiy, $520 \mathrm{~s}$.

[12] Zakirov, S. (1998). Razrabotka gazovykh, gazokondensatnykh i neftegazokondensatnykh mestorozhdeniy. Moskva, Rossiya: Struna, 628 s.

[13] Zakirov, S. (1980). Teoriya i proyektirovanie razrabotki gazovykh $i$ gazokondensatnykh mestorozhdeniy. Moskva, Rossiya: Nedra, $334 \mathrm{~s}$.

[14] Zakirov, S. (2000). Sovershenstvovanie tekhnologii razrabotki mestorozhdeniy nefti i gaza. Moskva, Rossiya: Graal, $643 \mathrm{~s}$.

[15] Rczaee, M., Rostami, B., \& Mojarad, M. (2013). Experimental determination of optimized production rate and its upscaling analysis in strong water drive gas reservoirs. International Petroleum Technology Conference, 1-11. https://doi.org/10.2523/IPTC-16938-Abstract

[16] Ter-Sarkisov, R.M. (2006). Tekhnologiya zakachki azota dlya dobychi zashchemlennogo i nizkonapornogo gaza. Gazovaya Promyshlennost', (4), 24-26.

[17] Yeske, G.A., \& Volik, A.I. (2015). Issledovaniye vliyaniya zakachki vykhlopnykh gazov na koeffitsiyent izvlecheniya kondensata. Neftegazovoye Delo, 13(2), 94-99.

[18] Sim, S.S.-K., Brunelle, P., Turta, A.T., \& Singhal, A.K. (2008). Enhanced gas recovery and $\mathrm{CO}_{2}$ sequestration by injection of exhaust gases from combustion of bitumen. SPE Symposium on Improved Oil Recovery. https://doi.org/10.2118/113468-ms

[19] Sim, S.S.K., Turta, A.T., Singhal, A.K., \& Hawkins, B.F. (2008) Enhanced gas recovery: factors affecting gas-gas displacement efficiency. Canadian International Petroleum Conference. https://doi.org/10.2118/2008-145

[20] Matkivskyi, S.V., \& Kondrat, O.R. (2020). Doslidzhennia efektyvnosti nahnitannia riznoho rodu nevuhlevodnevykh haziv na mezhi pochatkovoho hazovodianoho kontaktu. Abstracts of VII International Scientific and Practical Conference, 22-24 https://doi.org/10.46299/ISG.2020.II.VII

[21] Kondrat, O., \& Matkivskyi, S. (2020). Research of the influence of the pattern arrangement of injection wells on the gas recovery factor when injecting carbon dioxide into reservoir. Technology and System of Power Supply, 5/1(55), 12-17. https://doi.org/10.15587/27065448.2020.215074

[22] Jikich, S.A., Smith, D.H., Sams, W.N., \& Bromhal, G.S. (2003). Enhanced gas recovery (EGR) with carbon dioxide sequestration: A simulation study of effects of injection strategy and operational parameters. SPE Eastern Regional Meeting. https://doi.org/10.2118/84813-ms

[23] Mamora, D.D., \& Seo, J.G. (2002). Enhanced gas recovery by carbon dioxide sequestration in depleted gas reservoirs. SPE Technical Conference and Exhibition, 1-9. https://doi.org/10.2118/77347-ms

[24] Oldenburg, C.M., Law, D.H., Gallo, Y.L., \& White, S.P. (2003). Mixing of $\mathrm{CO}_{2}$ and $\mathrm{CH}_{4}$ in gas reservoirs: Code comparison studies. Greenhouse Gas Control Technologies $-6^{\text {th }}$ International Conference, 443-448. https://doi.org/10.1016/b978-008044276-1/50071-4

[25] Turta, A.T., Sim, S.S.K., Singhai, A.K., \& Hawkins, B.F. (2008). Basic investigations on enhanced recovery by gas - gas displacement. Journal of Canada Petroleum Technology, 47(10), 1-6. https://doi.org/10.2118/08-10-39

[26] Matkivskyi, S., Kondrat, O., \& Burachok, O. (2020). Investigation of the influence of the carbon dioxide $\left(\mathrm{CO}_{2}\right)$ injection rate on the activity of the water pressure system during gas condensate fields development. Global Trends, Challenges and Horizons, 1-10. https://doi.org/10.1051/e3sconf/202123001011

[27] Al-Hashami, A., Ren, S.R., \& Tohidi, B. (2005). $\mathrm{CO}_{2}$ injection for enhanced gas recovery and geo-storage reservoir simulation and economics. SPE Europec/EAGE Annual Conference and Exhibition, 1-7. https://doi.org/10.2118/94129-ms

[28] Akindele, F., \& Tiab, D. (1982). Enhanced gas recovery from waterdrive reservoirs - methods and economics. $57^{\text {th }}$ Annual Fall Technical Conference and Exhibition of Society of Petroleum Engineers, 1-6. https://doi.org/10.2118/11104-ms

[29] Burachok, O.V., Pershyn, D.V., Matkivskyi, S.V., Bikman, Ye.S., \& Kondrat, O.R. (2020). Osoblyvosti vidtvorennia rivniannia stanu hazokondensatnykh sumishei za umovy obmezhenoi vkhidnoi informatsii. Rozvidka ta Rozrobka Naftovykh i Hazovykh Rodovyshch, 1(74), 82-88. https://doi.org/10.31471/1993-9973-2020-1(74)-82-88

[30] Burachok, O.V., Pershyn, D.V., Matkivskyi, S.V., \& Kondrat, O.R. (2020). Doslidzhennia mezhi zastosuvannia PVT-modeli "chornoi nafty" dlia modeliuvannia hazokondensatnykh pokladiv. Mineral'ni Resursy Ukrayiny, (2), 43-48. https://doi.org/10.31996/mru.2020.2.43-48

\section{Дослідження впливу тривалості періоду нагнітання діоксиду вуглецю на коефіціснт вилучення газу при розробці газоконденсатних родовищ за водонапірного режиму}

\section{С. Матківський, О. Кондрат}

Мета. Дослідження процесу нагнітання діоксиду вуглецю на межі початкового газоводяного контакту з метою сповільнення просування пластової води в продуктивні поклади та підвищення кінцевих коефіцієнтів вуглеводневилучення.

Методика. Для оцінки впливу на коефіцієнт газовилучення тривалості періоду нагнітання діоксиду вуглецю на початковому газоводяному контакті виконано дослідження розробки покладу із використанням основних інструментів гідродинамічного моделювання Eclipse та Petrel компанії Schlumberger на прикладі гіпотетичної тривимірної моделі газоконденсатного покладу.

Результати. Встановлено залежність основних технологічних показників розробки покладу від тривалості періоду нагнітання діоксиду вуглецю на початковому газоводяному контакті. Визначено, що збільшення тривалості періоду нагнітання невуглеводневого газу призводить до зменшення накопиченого видобутку пластової води. Встановлено, що при нагнітанні діоксиду вуглецю забезпечується створення штучного бар'єру, завдяки якому частково блокується просування пластової води в газонасичені інтервали продуктивного горизонту. Кінцевий коефіцієнт газовилучення при нагнітанні діоксиду вуглецю становить 61.98\%, а при розробці покладу на виснаження - 48.04\%. Результати проведених досліджень свідчать про технологічну ефективність нагнітання діоксиду вуглецю на межі початкового газоводяного контакту з метою сповільнення просування пластової води в продуктивні поклади та збільшення кінцевого коефіцієнту вуглеводневилучення для умов конкретного покладу.

Наукова новизна. Визначено оптимальне значення тривалості періоду нагнітання діоксиду вуглецю на початковому газоводяному контакті, що становить 16.32 місяці на основі статистичної обробки розрахункових даних для умов конкретного покладу.

Практична значимість. Використання результатів проведених досліджень дозволяє вдосконалити існуючі технології розробки продуктивних покладів при водонапірному режимі та підвищити кінцевий коефіцієнт вуглеводневилучення.

Ключові слова: 3D модель, родовище вуглеводнів, газоконденсатний поклад, водонапірний режим, нагнітання діоксиду вуглеињю 
Исследование влияния продолжительности периода нагнетания диоксида углерода на коэффициент
извлечения газа при разработке газоконденсатных месторождений в условиях водонапорного режима

\section{С. Маткивский, А. Кондрат}

Цель. Исследование процесса нагнетания диоксида углерода на границе начального газоводяного контакта с целью замедления продвижения пластовой воды в продуктивные залежи и повышения конечных коэффициентов извлечения углеводородов.

Методика. Для оценки влияния на коэффициент извлечения газа продолжительности периода нагнетания диоксида углерода на начальном газоводяном контакте выполнено исследование процесса разработки залежи с использованием основных инструментов гидродинамического моделирования Eclipse и Petrel компании Schlumberger на примере гипотетической трехмерной модели газоконденсатной залежи.

Результаты. Установлена зависимость основных технологических показателей разработки залежи от продолжительности периода нагнетания диоксида углерода на начальном газоводяном контакте. Определено, что увеличение продолжительности периода нагнетания неуглеводородного газа приводит к уменьшению накопленной добычи пластовой воды. Установлено, что при нагнетании диоксида углерода создается искусственный барьер, благодаря которому частично блокируется продвижение пластовой воды в газонасыщенные интервалы продуктивного горизонта. Конечный коэффициент извлечения газа при нагнетании диоксида углерода составляет $61.98 \%$, а при разработке залежи на истощение - $48.04 \%$. Результаты проведенных исследований свидетельствуют о технологической эффективности нагнетания диоксида углерода на границе начального газоводяного контакта с целью замедления продвижения пластовой воды в продуктивные залежи и увеличения конечного коэффициента извлечения углеводородов для условий конкретной залежи.

Научная новизна. Определено оптимальное значение продолжительности периода нагнетания диоксида углерода на начальном газоводяном контакте, которое составляет 16.32 месяца на основе статистической обработки расчетных данных для условий конкретной залежи.

Практическая значимость. Использование результатов проведенных исследований позволяет усовершенствовать существующие технологии разработки продуктивных залежей при водонапорном режиме и увеличить конечный коэффициент извлечения углеводородов.

Ключевые слова: $3 D$ модель, месторождение углеводородов, газоконденсатная залежь, водонапорный режим, нагнетание диоксида углерода 